ROCZNIKI HUMANISTYCZNE

Volume 66, issue $2-2018$

SELECTED PAPERS IN ENGLISH

DOI: http://dx.doi.org/10.18290/rh.2018.66.2-5se

DOROTA WEREDA

\title{
THE ATTITUDE OF UNIATE BISHOPS \\ TOWARDS CALENDAR REFORMS \\ IN THE LATTER HALF OF THE $18^{\mathrm{TH}}$ CENTURY
}

On 24 February 1582, Pope Gregory XIII issued the bull Inter gravissimas pastoralis officii nostri curas, whereby on 5 October of that year the use of the current calendar was to be discontinued and a new style adopted. In the Polish Republic, King Stephen Báthory ordered the immediate introduction of the new calendar. This decision took on both a political and religious flavour, becoming the subject of many debates. In Grodno [Bel. Гродна] on 21 January 1584, in the face of resistance, the king issued a universal recommending the exercise of freedom to celebrate religious feasts by followers of religions still using the old calendar. He reiterated these provisions on 18 May and 1 July 1585 and 8 September 1586, noting that believers of the Orthodox Church in particular had the right to use the old calendar. In the Polish Republic, in contrast to the followers of the Reformation, who adopted the new style relatively quickly after 1644 once and for all, ${ }^{1}$ the Orthodox Church took a decidedly opposing stance. The inflexible attitude of the orthodox believers - for reasons related to religion and prestige-became part of the process of building their own identity and individuality. This differentiating element had so much significance that when the terms of

Dr DoROTA WEREDA is an assistant professor at the Institute of History and International Relations of the Siedlce University of Life Sciences and Humanities; email: weredad@uph.siedlce.pl

The Polish version of the article was published in Roczniki Humanistyczne vol. 59, issue 2 (2011).

${ }^{1}$ The project was funded by the National Science Centre on the basis of decision no. DEC2011/03/B/HS3/04845.

Marzena LIEDKE, "Recepcja kalendarza gregoriańskiego przez litewską jednotę ewangelicko-reformowaną w świetle akt synodalnych i korespondencji. Jeszcze jeden przyczynek do dziejów wprowadzania reformy gregoriańskiej w Rzeczypospolitej," in Człowiek wobec miar i czasu w przeszłości, edited by Marzena Liedke and Piotr Guzowski (Kraków: Wydawnictwo Avalon, 2007), 83-85. 
the Union were being formulated the Orthodox Church was not required to introduce the Gregorian calendar. For this reason, the measurement of elapsing time and the sense of sacred time became one of the most apparent features of distinctiveness for followers of various religions. Although during the phase of negotiations preceding the Union of Brest the commission of cardinals raised the issue of the calendar, deeming the readiness to adopt the new style as proof of the sincerity of the Uniate intentions, the bishopstaught by their experience of trying to introduce the Gregorian calendarwere aware that the decision to make the change would reduce the chance for peaceful implementation of the union. ${ }^{2}$ Nonetheless, the Orthodox bishops took a position not to oppose the introduction of the Gregorian calendar, were it necessary, but they requested that the principles of celebrating Easter, the Epiphany with its ceremony of blessing water, and that all holidays alien to the Latin tradition be preserved. ${ }^{3}$ The preservation of the old style in the Uniate Church created a feeling among the elite that this was the result of calculation leading to the conclusion that a transition to a corrected calendar would significantly reduce the ability to gain influence among the inhabitants the Polish Republic.

There were voices among the hierarchs that the measure of the calendar was neutral for the doctrine. Therefore, after the year 1596 the Roman Catholic Church was expected to endorse the right to use the old calendar and to abandon the debate or even mockery surrounding the "Russian month." In the $17^{\text {th }}$ century, the topic of the calendar was still present in many polemics between the Eastern Orthodox and Uniates. Demands to unify the dates of feast days were formulated in the works of the Uniate polemicists Kasjan Sakowicz and Jan Dubowicz. They enhanced their proposals with vivid examples of possible complications resulting from different dates of holidays in cultural, economic and even culinary aspects. ${ }^{4}$

The Synod of Zamość (1720) dealt with the organisation of the holiday calendar. The official list of church holidays adopted by the Synod of Zamość included 26 permanent holidays, six movable holidays and three particular holidays (a total of 35 public holidays, except Sundays). The

\footnotetext{
${ }^{2}$ Przemysław NowaKowski, Problematyka liturgiczna w międzywyznaniowej polemice po Unii Brzeskiej (1596-1720) (Kraków: Wydawnictwo Naukowe PAT, 2004), 56.

${ }^{3}$ Documenta Unionis Berestensis eiusque auctorum (1590-1600), edited by Athanasius Welykyi (Romae, PP. Basiliani, 1970), 61-66; Przemysław NowAKOwSKI, Problematyka liturgiczna, 50-51.

${ }^{4}$ David A. Frick, "Dzwony Wilna: mierzenie czasu w mieście wielu kalendarzy," in Czas i kalendarz, edited by Zdzisław Kijas (Kraków: Papieska Akademia Teologiczna, 2001), 261-264.
} 
synod prescribed that the faithful be free from service labour on feast days. At the same time, the synod called on the nobility to permit their subjects to attend Mass on a feast day or Sunday, ordering that the faithful not spend these days shopping at fairs, drinking, dancing and doing other secular activities. The calendar of holidays established by the synod was as follows:

- January: 1. Circumcision of Christ, 6. Epiphany, 30. Three hierarchs: Basil the Great, Gregory of Nazianzus, John Chrysostom

- February: 2. Purification of the Blessed Virgin Mary

- March: 25. Annunciation of Our Lord to the Blessed Virgin Mary

- April: 23. St. George the Martyr

- May: 8. St. John the Apostle and Evangelist, 9. Transfer of the relics of St. Nicholas

- June: 24. Birth of St. John the Baptist, 29. St. Apostles Peter and Paul

- July: 20. St. Elijah the Prophet, 25. St. Anna

- August: 6. Transfiguration of the Lord, 15. Dormition of the Blessed Virgin Mary, 29. The Beheading of St. the Baptist

- September: 8. Birth of the Blessed Virgin Mary, 14. Exaltation of the Holy Cross, 16. St. Josaphat Kuntsevych , 26. The Memorial of the Death of St. John the Apostle and Evangelist

- October: 1. Care of the Mother of God

- November: 8. St. Michael Archangel, 21. Presentation of the Blessed Virgin Mary in the Temple

- December: 6. St. Nicolas, 9. The Immaculate Conception of the BVM, 25. Birth of Jesus, 26. St. Joseph, 27. St. Stephen, the First Martyr.

Movable holidays were also added as obligatory: the three days of Easter, Ascension, Pentecost, Corpus Christi and Our Lady of Sorrows (the sixteenth day after Easter). Local holidays were also taken into account: 27 July-St. Pantaleon, a martyr in Volhynia, and 2 May and 24 July-St. Roman and St. David in Lithuania. ${ }^{5}$ There was also the practice of bishops compiling lists of holidays of obligation in particular dioceses. For example, in 1752 Bishop Teofil Godebski established the order of holidays for the officials of the Diocese of Volodymyr-Brest [Pol. Diecezja wtodzimiersko-

\footnotetext{
${ }^{5}$ Synodus provincialis ruthenorum habita in civitate Zamostiae anno 1720 (Romae, Typis Sacrae Congregationis de Propaganda Fide, 1883), 120-122; Stanisław NABYwANIEC, Unicka archidiecezja kijowska w okresie rzqdów arcybiskupa metropolity Felicjana Filipa Wotodkowicza 17621778 (Rzeszów: Poligrafia Wyższego Seminarium Duchownego w Rzeszowie, 1998), 413-414.
} 
-brzeska, Rus. Владимирская и Брестская епархия], which did not introduce any changes to the order established during the Synod of Zamość. ${ }^{6}$

The celebration of holidays posed difficulties due to discrepancies between the Gregorian calendar (used by the Latin Church) and the Julian calendar (used by the Uniate Church). Celebrating became particularly troublesome in the eastern territories of the Polish Republic, inhabited by followers of both Greek and Latin rites. In the Latin Rite Church of the Post-Tridentine era, in addition to the 38 days of proper celebration, the faithful were to participate in Holy Mass (after which they could go to work) on 15 other days. With Sundays included this amounted to 90 complete days and 15 incomplete days. $^{7}$ After the inclusion of 35 feast days, celebrated in the Unite Church according to the Julian calendar, it turned out that in the lands inhabited by the faithful of both rites, days off work were a total of four and a half months. Such a large amount of public holidays no doubt disorganised work in the countryside, especially during seasons of intensive fieldwork. This certainly caused inconvenience, especially on farms whose functioning was based on the work of subjects of both rites. It seems that this problem had lesser social impact in towns, where work could be organised differently. Cultural relations between Catholics of the Latin and Greek rites living in urban space were transformed due to the operation of multicultural cities in the Polish Republic. Distinct measures of time for celebration and for work were used by the followers of Judaism, i.e. Karaims and Armenians.

The issue of calendar regulation was revived during the reign of King Stanisław Poniatowski, encouraged by the ideas of the Enlightenment and destabilization of the political and religious situation. The changes introduced in the Latin Rite Church provided a powerful stimulus for animated discussion in the circles of the Uniate hierarchs. In the middle of the $18^{\text {th }}$ century, Pope Benedict XIV, who held dear the ideas of the Catholic Enlightenment, significantly reduced the number of feast days. Having recognised the arguments put forward in 1743 by the Bishop of Vilnius [Pol. Wilno], Mikołaj Zieńkowicz, and in 1745 those provided by Teodor Potocki, the Bishop of Poznan, that peasants would work harvesting and ploughing despite the church ban, consented that feast days in the summer months (July, August and September), except for the Assumption of the Blessed

\footnotetext{
${ }^{6}$ The State Archive in Lublin (hereinafter abbreviated as SAL), the Greek Catholic Consistory in Chełm (hereinafter abbreviated as GCCCh), ref. file no. 758, 21.

${ }^{7}$ Jan KRACIK, “'Nieposłuszne Kościołowi Dziatki.' Reakcja społeczna na papieską redukcję świąt w Polsce w 1775 r.” Analecta Cracoviensia 26 (1995): 502.
} 
Virgin Mary, should be moved to Sundays. These partial concessions for selected dioceses caused disruption. Therefore, the Sejm and the King turned to the Pope requesting this issue to be regulated. Pius VI issued the breve Paternae charitati on 23 May 1775 specifying a list of 16 holidays henceforth applicable in the Polish Republic (Easter and Pentecost together with the following Monday, Christmas, Circumcision of Christ, Epiphany, Ascension Day, Corpus Christi, Immaculate Conception of the BVM, Annunciation of Our Lord to BVM, Purification of the BVM, Assumption of the BVM, Feast of Saints Peter and Paul, All Saints, Feast of Saint Stephen, and the feast of the principal patron saint of the diocese). The Pope expected that the observance of a reduced number of holidays, a ban on fairs and concessions for the subjects would be more beneficial. In order not to cause dissatisfaction among peasants, bishops appealed in their pastoral letters not to impose serfdom on days with cancelled holidays. The papal nuncio Giuseppe Garampi also brought this to public attention. The papal decision aroused disapproval of some of the clergy. ${ }^{8}$ In 1784 , as a result of pressure from the Armenian seniors, the Holy See agreed that the Armenians might adopt the Gregorian calendar. ${ }^{9}$

The circumstances of the day also prompted the Uniate Church to take up the issue. The introduction of a unified calendar which would be adapted to the calendar used in the Latin Church was proposed by Maksymilian Ryłło, the bishop of the Diocese of Chełm. He raised this issue in a letter of 2 February 1774 addressed to Nuncio Garampi. He wrote that a lot of dispute and misunderstanding arose around this project. ${ }^{10} \mathrm{~A}$ surprising proposal was made in 1775 to the Governor of Pskov [Pol. Psków] General-Major Mikhail Krechetnikov by the then Archbishop of Polotsk [Pol. Połock] Jason Smogorzewski, in which it was recommended to the new bishop of the Latin Rite, Stanisław Siestrzeńcewicz (a co-adjutor in the diocese of Vilnius from 1773), that the Julian calendar be introduced. The unification was intended to eliminate the inconvenience created by the differences "when one festive man sleeps or drinks and another man toils." Making reference to the arguments used of the majority, he invoked the example of "Greeks" living in Rome (probably the faithful of the Uniate Church). They adhered to the Roman

\footnotetext{
${ }^{8}$ Ibid., 505-509.

${ }^{9}$ Krzysztof Stopka, Ormianie w Polsce dawnej i dzisiejszej (Kraków: Księgarnia Akademicka, 2000), 141.

${ }^{10}$ Холмский греко-униатский месяцеслов на 1873 год (Варшава: тип. И. Яворского, 1872), 95.
} 
calendar. Smogorzewski also proposed that the general-governor should recommend that Catherine II move all feast days to Sundays. Farmers and craftsmen working longer hours would become richer, it would be easier for them to discharge their obligations and they would be able to work a whole week according to their conscience. ${ }^{11}$ It is difficult to understand Smogorzewski's economically motivated convictions in the context of his activity as Archbishop of Polotsk, and then as a metropolitan involved in many patriotic initiatives. In later years, he was seen by Russia as being not in favour of it, and this animosity was such that after accepting the dignity of a metropolitan bishop he was forced to leave the borders of the Russian state. Smogorzewski's proposals can be interpreted as an element of a risky game with Stanisław Siestrzeńcewicz, loyal to the tsarist authorities and supported by them, who was reluctant towards the Uniates. Although this was not the official position of the whole Uniate episcopate, but only the voice of an influential hierarch, it may indicate that the unification of the calendar was not tantamount to acceptance of the Gregorian calendar and the order of holidays in force in the Latin Church.

The reduction in the number of days off work for the subjects of the Latin rite contributed to the formulation of proposals by the nobility to introduce restrictions for the subjects of the Greek rite. Debate surrounding the calendar intensified in the $1880 \mathrm{~s}$. Bishops had to react to signals of alarming events prompted by differences in the dates of feast days. The most influential dignitaries of the Uniate Church took part in consultations regarding this issue: Metropolitan Bishop Jason Junosza Smogorzewski, the Bishop of Chełm and Metropolitan Coadjutor of the Metropolitan Teodozy Rostocki, Bishop of Lviv Piotr Bielański, the protoarchimandrite of the Basilian Order, the Bishop of Chełm Porfiry Skarbek-Ważyński since 1790, and Stefan Lewiński, a titular bishop of Tegea, auxiliary bishop of the Metropolitan, secretary of the Royal Cabinet. A special role in the escalation of the problem was played by Andrzej Ignacy Ogiński, Voivode of Trakai [Pol. Troki] (1784-1787). The pursuit of changes was most probably part of his innovations intended to improve the functioning and economic performance of the landed estate covering the lands inherited from his father (the Isabelin estate in the district of Oszmiany) and his childless aunt Helena Oginska (in Pod-

\footnotetext{
${ }^{11}$ Акты издавемые Виленскою археографическою коммисиею для разбора древних актов, vol. 16, Vilna, 1889, 426.
} 
lasie Region, near Sokołów). ${ }^{12}$ In the light of the correspondence between Bishop Lewiński and Metropolitan Bishop Smogorzewski from July 1785, Ogiński put forward a proposal to move feast days to Sundays and through Lewiński tried to bring this matter to the attention of the metropolitan. Lewiński argued the need for changes in the following manner:

In Lithuania and Podlasie, a reduction in the number of holidays, that is a translation, is needed because gentlemen, by themselves, per modum facti, to avoid inconvenience on their farms, drive Ruthenians to churches with their scourges and order them to be Latin Catholics wherever there are subjects of mixed rites. ${ }^{13}$

In this regard, the voivode also addressed the metropolitan bishop directly. In a letter dated 26 July 1785, he presented slightly less radical solutions, limiting the territorial and chronological scope of the proposed changes. He suggested that in the territory of Lithuania the metropolitan move some feasts to Sundays, or at least grant a dispensation regarding his property so that holidays falling during periods of intensive fieldwork, i.e. "from Easter to St. Martin's Day," would be transferred to Sundays. He promised that "manors under the duty of conscience will see that the peasant celebrate at least Sundays and not do any work." 14 The metropolitan did not show haste. On 2 May 1786, Bishop Lewiński informed Bishop Bielański that the memorial concerning the reduction in the number of holidays was sent back to Smogorzewski, writing "but I do not know when the Old Man will care to write back." At the same time, he asked the addressee to intervene in that matter with the metropolitan. ${ }^{15}$ Bielański addressed that issue in a letter to Smogorzewski dated 28 July 1786, but he did not mention Lewinski's insistence, who at the time resided in Warsaw. The reason that he gave was a letter he had received from the nobility of Podolia [Pol. Podole] together with a petition to reduce the number of public holidays drawing on

\footnotetext{
${ }^{12}$ In 1783, Andrzej Ignacy Ogiński carried out a reform consisting in new division, consolidation and development of land, thus causingclashes with peasants inhabiting the starostwo [local administrative unit similar to county - Translator's note]. He also tried to capture his involvement in a theoretical manner, writing a work intended to be a manual entitled "Instruktarz ekonomiczny dla ludzi będącej w służbie gospodarczej” [An economic manual for people employed to do service labour]. See Zofia ZielińSKA, "Ogiński Andrzej," in Polski Stownik Biograficzny, vol. 23 (Wrocław -Kraków: Zakład Narodowy Im. Ossolińskich, 1978) [henceforth abbreviated as PSB].

${ }^{13}$ Акты издавемые, p. 362.

${ }^{14}$ Ibid.

${ }^{15}$ Центральний державний історичний архів Украӥни у Львові [Central Historical Archives of Ukraine in Lviv, henceforth referred to as Lviv Archive), Fond 684, op. 1, ref. file no. 1763, p. 1.
} 
the calendar used by the faithful of the Latin rite. Bielański assured that he was also personally in favour of this demand. ${ }^{16}$ In his report on the situation of the sejmiks in Chełm and Volodymyr addressed to Smogorzewski on 10 August 1786, Rostocki informed that the reduction in the number of holidays and the discussion on the calendar stirred "continuous anxiety." 17 In a letter to Smogorzewski dated 12 June 1787, the Bishop of Chełm Diocese Ważyński tried to present a solution to the problem, analysing the wider social and religious context and recommending far-reaching caution in this regard. $\mathrm{He}$ presented his reflections to the metropolitan in the following way:

\begin{abstract}
We remain between two opposing circumstances. In Ukraine and Kiev Polesie, people need to maintain the old style in their rituals; following other dioceses, they need what has already been licitly or illicitly introduced. It is necessary to reconcile very subtly and carefully one with the other and slowly subject them to certain discipline, so as not to dissuade some from unity and others from rituals.
\end{abstract}

He insisted that the calendar reforms be accorded the status of a matter of state importance and the King and the Sejm be involved. He pointed out that modifications to the calendar might also have negative consequences for the Uniate Church:

\begin{abstract}
The unification of the calendar and holidays with regard to their solemn preservation by the common folk reduction is needed in our countries; but as His Lordship has always deemed appropriate, first of all, we need to use the authority of His Majesty or the estates themselves so that all the congregations that are inconsistent with us in their faith and keeping the old calendar will accept the new calendar; otherwise they would be impeded in their acceptance of unity, being fond of the old calendar, and on the contrary, having adopted the new calendar, they would therefore be different from foreigners, and in a way they would be prepared to become united with the Orthodox. ${ }^{18}$
\end{abstract}

Despite his scepticism towards the reform of the calendar of the Unite Church, in another letter of 15 June 1787, Ważyński confirmed the need for a new calendar because the subjects were forced to work on holidays, as well as endorsing the written interventions of the Metropolitan in this matter with the Royalty and at the papal nuncio. At the same time, he reiterated his demand that dissidents be obliged to introduce the new calendar, as doing this

\footnotetext{
${ }^{16}$ Акты издавемые, р. 410.

${ }^{17}$ Холмский греко-униатский месяцеслов на 1875 год (Варшава: тип. И. Яворского, 1874), $109-110$.

${ }^{18}$ Акты издавемые, 401.
} 
only among the Uniates could induce the faithful living in the "Ukrainian Rus" to convert to the Orthodox Church. Ważyński proposed that these changes should be introduced during the deliberations at the meeting of bishops, pointing out that the modification of the calendar would result in alterations in the liturgical books. ${ }^{19}$ He illustrated the economic background of misunderstandings arising from differences between the calendars by describing to Smogorzewski (on 13 August 1787) the events in the parish in Wirów (the Diocese of Volodymyr-Brest). ${ }^{20}$ Jan Kuszel, the new owner of Wirów, used violence to dissolve the local Uniate parish. Apart from demolishing the church building, depriving the clergyman of its benefice and banning any religious practices in the Greek rite, he undertook to eliminate calendar differences.

In 1788-1791, on holidays prescribed by the Julian calendar, the faithful were forced to work, and on days of fasting, the court staff would carry out home inspections to check whether meals of meat were eaten. Pastor Grzegorz Werpechowski unsuccessfully appealed to the court in Drohiczyn and offices of the Austrian administration in Siedlce; he pleaded with the Commission for the Rights of the Russian Rite. These events had a great deal of publicity. ${ }^{21}$ Ważyński informed the metropolitan bishop that the same was happening in Mosarz, ${ }^{22}$ and while he was visiting a parish in Lithuania, he faced threats that the subjects would be forced to change their rites due to the incompetence of priests, a great number of holidays and fasting days occurring at different times. He reported that a nobleman named Pruszyński distributed printed information among the Lithuanian nobility concerning the draft changes. Under such circumstances, Ważyński asked the metropolitan bishop to make haste in this matter. In reply, Smogorzewski explained to the Lithuanian nobility that work on the bill had already begun, and that it was dissidents who impeded its completion as they were opposed to the new calendar. ${ }^{23}$ This seems to have been the most important reason why the

\footnotetext{
${ }^{19}$ Ibid.

${ }^{20}$ Ibid., 404-405.

${ }^{21}$ Холмский греко-униатский месящеслов на 1872 год (Варшава: тип. И. Яворского, 1871), 87-88; Aleksander Kossowski, Blaski i cienie unii kościelnej w Polsce w XVII-XVIII wieku w świetle źródeł archiwalnych (Lublin: [publisher not identified], 1939), 23.

${ }^{22}$ Ważyński probably mentioned the town of Mosarz in the powiat of Dzisna (Bel. Дзісна) (Stownik geograficzny Królestwa Polskiego i innych krajów stowiańskich, vol. 6, edited by Filip Sulimierski, Bronisław Chlebowski and Władysław Walewski (Warszawa: Wyłącznym Nakładem Władysława Walewskiego, 1885, 691)).

${ }^{23}$ Акты издавемье, 404-405.
} 
metropolitan was against alterations to the calendar. He intended to entrust the solution of the problem to a whole group of bishops. Ważyński (13 August 1787) mentioned the synod being envisaged by the Metropolitan, which would "remedy the novelties introduced to the rite." ${ }^{24}$ In 1788, consultations among the hierarchy continued. Smogorzewski (15 January 1788) expressed his appreciation for Bielański's remarks, which served as an argument against the unification of the calendar for the Uniate Church and the Roman Catholic Church. ${ }^{25}$

The religious and political dimension of the calendar reforms is confirmed by the circumstances surrounding the establishment of an Eastern Orthodox bishop Wiktor Sadkowski in the Polish Republic. The Uniate hierarchy took every opportunity to prevent him from obtaining a royal privilege for the cathedral in Slutsk (Pol. Słuck). Smogorzewski's trusted man in this matter was Lewiński, who was in charge of the practical side, while Rostocki was a consultant who tried to develop the concept and strategy. The Metropolitan, as the one who was better informed about the political situation and having more experience in relations with Russia, was the first to understand the impossibility of blocking the appointment of an Orthodox bishop in Poland, so he motioned that the terms and conditions of Sadkowski's activity be defined. Formulated by Smogorzewski, they were finally edited by Lewiński into a list of 24 items entitled Minuta sponsionis Danae per novum episcopum nonunitum in Polonia. Among the desiderata forcing the future hierarch of the Eastern Orthodox Church to be loyal to the King and the Polish Republic, there was an item (no. 21) concerning the calendar. It was postulated that in a situation where the state authorities considered it necessary to introduce a uniform calendar and reduce the number of feast days, the Orthodox Church, like the Uniate Church, should be obliged to adopt and implement this regulation. ${ }^{26}$

Lewiński submitted a letter containing the desiderata to the King on $16 / 27$ September 1789, conscious of the slight chance of changing the situation. Another opportunity to enforce the obligations imposed on Bishop Sadkowski was seen in the moment when the royal privilege was granted. It was hoped that this event would provide a possibility of negotiating the transfer of feast days to Sundays and the adoption of the new calendar in the

\footnotetext{
${ }^{24}$ Ibid., 402.

${ }^{25}$ Lviv Archive, Fond 491, op. 1, ref. file no. 29, 2, sheet 77.

${ }^{26}$ Eugeniusz SAKOwicz, Kościót prawosławny w Polsce w epoce Sejmu Wielkiego (Warszawa: Warszawska Metropolia Prawosławna, 1935), 42-43.
} 
Orthodox Church. ${ }^{27}$ Conferral of the privilege and presentation of the document of nomination were prevented by the absence of Deputy Chancellor Chreptowicz, who was out of Warsaw holidaying. His prolonged absence from the capital led Rostocki to urge (10 October 1786) Smogorzewski to seek the appointment of new ministers in order not to expose the Republic and religion to serious consequences. Rostocki also insisted that while taking advantage of the currently favourable circumstances - which he believed were: the debate on settling various matters between followers of different denominations, the appointment of Bishop Sadkowski, Sejm deliberations and the presence of the apostolic nuncio-the Orthodox believers be pressed to accept the new calendar and reduce the number of feast days. When formulating these demands, Rostocki had no up-to-date information. Sadkowski was presented the document of the nomination privilege-sent by Chreptowicz to Warsaw-by the King through Mr Stackelberg on 6/17 September 1786 on the very same day without any conditions. ${ }^{28}$ The favourable opportunity to negotiate the calendar was lost, but further efforts were not abandoned by the Uniate hierarchy, though. Sadkowski's visit to the capital, prolonged by his futile anticipation of the chance to give personal thanks to the King, turned out to be a good reason for many informal meetings "over tea and punch" between Lewiński and the new Orthodox bishop. The new Orthodox bishop's views were now being probed, also with respect to the calendar. As we learn from Sadkowski's own accounts, the bishop replied to Lewinski that in the case of the synod's acceptance he would not oppose that. ${ }^{29}$

In the influential Uniate circles attempts were made to confront the issue of calendar unification again during the meeting in order to thank the King and for Sadkowski to swear an oath, which were attempted when King Stanisław August Poniatowski arrived to meet with Catherine II. Despite initial plans to take the oath in Kaniv (Pol. Kaniów), which was supposed to make an impression on the numerous witnesses of the ceremony, they fell through. Finally, Sadkowski took the oath on 7/18 May in Tulchyn (Pol. Tulczyn). Efforts of the Uniates to unify the liturgical calendars used in the Uniate Church and the Eastern Orthodox Church fell through yet again. The ceremony and the swearing of the oath took place in accordance with the instructions of the Russian court. ${ }^{30}$

\footnotetext{
${ }^{27}$ Ibid., $47-48$.

${ }^{28}$ Акты издавемые, 398; Eugeniusz SAKOwicz, Kościót prawosławny, 53-55.

${ }^{29}$ Акты издавемые, 373-379.

${ }^{30}$ Eugeniusz SAKOwicZ, Kościót prawostawny, 60-61; Andrzej A. ZIĘBA, "Smogorzewski Jason," in PSB, vol. 39 (Warszawa-Kraków: Zakład Narodowy Im. Ossolińskich, 1999), 223.
} 
Determination visible in the activities of the Unite hierarchy with respect to the calendar confirms the religious, social and political importance of the measuring system which governs the rhythm of work and feast days. Adherence of the faithful to the old order in the calendar must have been considerable since it inspired fears of the Uniate faithful converting to the Orthodox Church. The calendar was interpreted by a significant proportion of society as a clear element identifying all the faithful and an important factor in the creation of individuality and sense of identity in the multidenominational and multinational Polish Republic. The Uniate hierarchs treated the pursuit of unification of liturgical calendars used in the Uniate Church and the Orthodox Church as a matter of state importance.

The next stage of work on the calendar in the Uniate Church was the time of the Great Sejm. In the atmosphere of state reforms, despite differences of opinion among the Uniate hierarchs, they addressed this problem seeing the urgent need for an urgent solution and thus introduction of a new myesatseslav (Ukr. месяиеслов). The degree of scepticism and disapproval of changes in the elite of the Uniate Church decreased after the death of Metropolitan Smogorzewski (1 November 1788). The bishop of Przemyśl, Maksymilian Ryłło (the bishop of Chełm Diocese in 1759-1784), who was known for his earlier activity promoting inspirations with the tradition of the Latin rite, was a supporter of the new solutions. In a note to the Lviv Governing Authority concerning the changes in the old myesatseslav, he referred to his participation in the talks of senior church dignitaries, held during his stay in Rome in 1742. One of the debaters was the Metropolitan of Bulgaria, Basilio Matranga, residing in Rome, who advocated unification of the calendars. The bishops of Croatia from the diocese of Krzyżowiec (Crisium/ Kreutz), Basilius Bosicskovich, a Basilian (1777-1785) and his successor Josaphat Bastassich presented a similar position. Ryłło also referred to talks with many Uniate hierarchs who were in favour of the "union of calendars": Florian Hrebnicki, the archbishop of Polotsk and later metropolitan (in 1744), Teofil Godebski, the bishop of Volodymyr-Brest (in 1749), as well as Filip Felicjan Wołodkowicz, the bishop of Chełm and then of VolodymyrBrest and a metropolitan, Jerzy Bulhak, the Bishop of Pinsk [Pol. Pińsk] and Turów, and Teodozy Rudnicki, the bishop of Lutsk. He had heard many times from everyone about the inevitable need to unify the calendars of the Catholic Churches. He also referred to the opinion of F. Hrebnicki, who argued that these changes would create noticeable and clear differences in perception between the Uniates and the followers of Eastern Orthodoxy. 
The congress of bishops held in Volodymyr in 1758 acknowledged this necessity. Ryłło also reminded the participants that this idea had been backed up by his predecessor Onufry Szumlański, the diocesan bishop of Przemyśl, who had once planned to table this issue for discussion in the Sejm. ${ }^{31}$ Referring to the opinions of eminent figures of the Uniate Church in the Polish Republic and foreign hierarchs, including those who were close to the Holy See, he wished to justify his strong beliefs and aspirations to unify the calendar-perceived as uncritical and cynically characterized by Ważyński like this: "he is pushing it with might and main." 32 It seems that Ryłło did not take into account the changes in the current religious and political situation in the eastern regions of the Polish Republic, the increasing role of the Orthodox Church, used as a tool of political influence of Russia in Poland, complicated social relations manifested in peasants' activities. Ryłło's beliefs were largely shaped by the political and religious situation in Austria and played a decisive role in his analysis of current affairs.

A much more cautious and balanced position on this issue was presented by Porphyry Ważyński. While monitoring the Sejm deliberations, during which motions were tabled for the introduction of the new calendar, he recommended in 1790 that the coadjutor bishop of the Diocese of VolodymyrBrest, Arseniusz Główniewski, gather the representatives of the diocese and submit the matter of establishing movable feasts for their consideration, taking into account the method of calculating years used in the Byzantine calendar. $^{33}$

At the forum of the Great Sejm, an animated debate on the calendar issue was started on 12 July 1790 when discussion on the status of the metropoli$\tan$ in the Senate took place. During the meeting, Lithuanian court treasurer Franciszek Dziekoński pointed out that the adoption of the Latin calendar would have a positive impact on the economy. The king took the floor in an exciting exchange of arguments, trying to balance the Enlightenment pursuit of unification and rational tolerance for individuality and the sense of identity manifested by a significant community of subjects. "I understand that it should be a uniform rule for us to disregard whatever these people believe to represent their difference and separateness," said Stanisław August. "And since the calendar makes the greatest difference, we need to make it equal.

\footnotetext{
${ }^{31}$ Антін Степанович ПЕтРшЕвич, “Краткое известие о Холмской епархии и святителях ея," in Холмский греко-униатский месяиеслов на 1874 год (Варшава: тип. И. Яворского 1873), 54-55.

${ }^{32}$ Ibid., 53.

${ }^{33}$ Ibid., 53-54.
} 
I know that this is not to be done abruptly. Let us therefore leave them their own separate feasts and fasting days, and if we do so, they will not know how it happened." ${ }^{34}$

This matter was also addressed by Kacper Cieciszowski (Bishop of Kiev), Mateusz Butrymowicz, Benedykt Hulewicz, Julian Ursyn Niemcewicz, Stanisław Kostka Potocki, who all warned that the standardisation could be used by the anti-Uniate propaganda to build significant support for the Eastern Orthodox Church among the faithful who were unconscious of the purpose of the changes. ${ }^{35}$ Sejm deputy Butrymowicz, in spite of the instructions demanding the standardisation, explained that only a few would be aware of the metropolitan's presence in the Senate, and the change of the calendar would be felt by everyone, which might stir social unrest. The discussion of this problem was ended by Bishop Cieciszowski, drawing everyone's attention to the fact that if the adoption of a new calendar and the appointment of a metropolitan were put forward as a condition, the Uniates would be under the impression that the followers of the Latin rite wanted to change their rights and customs, which would cause the faithful lose their trust in Rostocki, and that the Republic could afford at the time. ${ }^{36}$

After the metropolitan of the Uniate Church obtained the right to sit in the Senate and after he was solemnly inducted as senator on 9 September 1790 , the reform of the calendar was addressed in no time. The matter called for rapid solutions, since as early as 17 September 1790, a congress was convened at the residence of the metropolitan in Warsaw. Led by the metropolitan, the following took part: Simeon Młocki, the bishop of VolodymyrBrest, Porfiry Ważyński, the bishop of Chełm-Bełżec, Stanisław Lewiński, co-adjutor of the metropolitan and administrator of the Diocese of Lutsk, and Josaphat Bulhak, the bishop of Turów and co-adjutor of Pinsk. The participants addressed the issue of reducing the number of feast days. Each of them submitted their proposals in writing to the metropolitan. The bishops' intention was to reduce the number of feast days in order to encourage better celebration on the preserved days and prevent persistent petitions from the nobility.

\footnotetext{
${ }^{34}$ Quoted after Agnieszka KnychalsKa, "Kwestia unicka w czasie Sejmu Czteroletniego," Studia z dziejów XVII i XVIII wieku, edited by Krystyn Matwijowski and Bogdan Rok (Wrocław: Instytut Historyczny Uniwersytetu Wrocławskiego, 2003), 166.

${ }^{35}$ Walerian KaLinKa, Sejm Czteroletni, vol. 2 (Warszawa: Wydawnictwo Wolumen, 19912), 276-279. Kamil PAŹDZIOR, "Dopuszczenie metropolity unickiego do senatu w 1790 r. Studium z polityki wyznaniowej Sejmu Czteroletniego,” Nasza Przeszłość 91 (1999): 257.

${ }^{36}$ Walerian Kalinka, Sejm Czteroletni, 278; Agnieszka KnYCHAlsKa, Kwestia unicka, 166.
} 
The Congress resolved to submit the proposals regarding the new calendar of feast days for the approval of the Holy See. The bishops gathered at the congress expressed their conviction that after the Holy See had approved the proposal of reducing holidays, in accordance with the will of the nobility and the king, the state (i.e. the king and the nobility) would induce the antiUniates to adopt the new order in the calendar, thus leading to its unification. It was proposed to dispense with 12 feasts in all parishes of the Uniate Church, and 13 in Lithuania and Volhynia. The plan was to reduce the largest number of feast days (two for each month, and three in Lithuania and Volhynia) in July and September, that is in the time of intensive fieldwork. The list of feast days to be abolished included: Three Holy Hierarchs (January), Saint George the Martyr (April), Translation of Relics of Saint Nicolas (May); in July: Feasts of Saint Anne, Saint Elijah the Prophet, Saints Roman and David (in Lithuania), Saint Panthelemon (in Volhynia); Beheading of Saint John the Baptist (August); Blessed Josaphat the Martyr, Saint John the Evangelist (September) in November: Care of the BVM and the movable feasts of Third Day of Easter, Third Day of Pentecost, Our Lady of Sorrows. According to the draft, the following holidays were to be preserved: in January-Circumcision of Christ, Epiphany; in February-Purification of the Blessed Virgin Mary; in March - Annunciation to the Blessed Virgin Mary; in June-Birth of Saint John the Baptist, Saints Peter and Paul; in August Transfiguration and Assumption of the BVM; in September-Nativity of the BVM, the Exaltation of the Holy Cross; in October-Care of the BVM; in November-Saint Michaelangelo, Blessed Josaphat the Martyr; in December-St. Nicholas, Immaculate Conception of the Blessed Virgin Mary, Flight into Egypt, St. Stephen, and mobile feasts: First and Second Easter Day, Ascension Day, First and Second Day of Pentecost, Corpus Christi. ${ }^{37}$

Finally, a memorial from the last congress of Uniate bishops and archimandrites in Poland was sent to the Holy See concerning the reduction of holidays. The congress took place in Volodymyr in February 1794 and was led by the Bishop of Volodymyr-Brest Symeon Młocki. ${ }^{38}$ The introduction of the new solutions was met with resistance. Even before the approval of the Holy See, bishops would allegedly "give dispensations" from the

\footnotetext{
${ }^{37}$ Epistolae metropolitarum Kioviensium catholicorum Theodosii Rostockyj, Heraclii Lisowskij, Gregorii Kochanowicz, Josaphat Bulhak 1788-1838, collegit, paravit, adnotavit editionemque curavit $P$ Athanasius $G$. Welykyj (Romae: PP. Basiliani, 1980), 75-81.

${ }^{38}$ Ludomir BIEŃKOwSKI, "Młocki Stefan," in PSB, vol. 21 (Wrocław-Warszawa-KrakówGdańsk: Zakład Naorodowy Im. Ossolińskich, 1976), 409.
} 
abolished holidays. ${ }^{39}$ The new list of celebrations, in addition to deletions, included the transfer of the feast of Blessed Josaphat Kuntsevych from September to November. On the basis of this change, made probably due to account for the autumnal season of field work, the original date of the feast of Josaphat Kuntsevych was restored, established during the beatification in 1643 to commemorate the anniversary of his martyrdom. In the latter half of the $17^{\text {th }}$ century, at the request of Metropolitan Cyprian Żochowski (16741693), who spoke on behalf of himself and the whole province of Polotsk, Pope Innocent XI gave permission to move the feast of the martyr to 16 September "for the convenience of celebrating the service on account of the dangerous and difficult crossing of the Dźwina River." ${ }^{40}$ In an attempt to revive the veneration of Kuntsevych's martyrdom who had suffered for the union but was now losing popularity mainly due to the growth of the Marian cult, the decision to change the date was reaffirmed by the resolutions of the synod in Zamość (1720), whereby the date of the holiday for the whole Unite Church in the Polish Republic was set at 16 September $\left(27^{\text {th }}\right.$ according to the Gregorian calendar). ${ }^{41}$ The decision to return to the November date for the feast was probably also justified by the waning cult of the martyr in the eighteenth century. The resolutions of the congress were restricted to a reduction in the number of festive days. No changes with respect to the dating discrepancy between the Julian and the Gregorian calendars were attempted.

The hierarchs of the Uniate Church also had to respond to changes in the calendar undertaken by the partitioning states. In the dioceses incorporated into the Austrian state, after the first partition, the authorities worked hard to unify the calendar by reducing the number of holidays celebrated in the Uniate Church. In fear of widespread dissatisfaction, on 26 September 1781, the Austrian Gubernium (governorate) was granted permission together with a court decree to reach an agreement with the bishops on this matter. In reply, the Bishop of Przemysl Ryłło wrote a comprehensive statement of

\footnotetext{
${ }^{39}$ Ludomir BIEŃKOwsKi, "Organizacja Kościoła wschodniego w Polsce," in Kościót w Polsce, edited by Jerzy KŁoczowsKi, vol. 2 (Kraków: Papieska Akademia Teologiczna, 1968), 882-883.

${ }^{40}$ Kazanie na uroczystość bt. Jozafata Kuncewicza, arcybiskupa potockiego, biskupa witebskiego, mścistawskiego, orszańkiego i mohilowskiego za jedność z Kościołem rzymskim męczennika miane w katedrze połockiej roku MDCCLXII przez X. Porfirego Ważyńskiego Z.S. Bazylego W., filozofii natenczas Professora, i przez Tegoż Wielmożnym Ichmościom Państwu Antoniemu i Eleonorze z Skarbków Ważyńskich Zenowiczom, woyskim województwa połockiego z okoliczności powinszowania dozgonnego szczęśliwie między Niemi zawartego Przymierza przypisane $w$ Wilnie w Drukarni J.K.M. u XX Bazylianów, sheet. 1.

${ }^{41}$ Alfons GuÉPIN, Życie S. Jozafata Kuncewicza (Lviv: Nakł. księg. Gubrynowicza i Schmidta, 1907), 411-412.
} 
reasons for the need to celebrate public holidays in accordance to the existing order, referring to the tradition and events of the Poland. This did not prevent the issuance of a decree on 1 March 1784, which ordered bishops to reduce the number of church holidays, motivating this decision with an excessive number of public holidays, which resulted, among other things, in people becoming indolent.

With regard to the question of reducing the number of feast days, Bishop Ryłło addressed two pastoral letters (11 March and 4 December 1784), in which he tried to explain the changes and convince the faithful to accept them. The changes would consist in moving three feasts to Sundays: Saint George (23 April), Saint Elijah (20 July), and Beheading of Saint John the Baptist (29 August).

The second stage of reduction was initiated as early as 1785 . At the request of the imperial court, Bishop Ryłło made a plan of moving as many as 15 out of 27 public holidays to Sundays. The final changes in the liturgical calendar took place after the court decree of 19 June 1787 was issued. As a result, the following feast days were left in the calendar: Circumcision of Christ, Epiphany, Saint Basil the Great, Gregory the Theologian and John Chrysostom, Presentation of Jesus, Annunciation to the Blessed Virgin Mary, Nativity of John the Baptist, Saints Peter and Paul, Transfiguration of the Lord, Assumption of the Blessed Virgin Mary, Exaltation of the Holy Cross, Saint Michael the Archangel, Presentation of the Blessed Virgin Mary, Saint Nicholas, Christmas, Saint Joseph and Saint Stephen, and movable holidays: Good Friday, Easter Monday and Tuesday, Ascension and the Monday of Pentecost. A new feast was introduced in honour of Saint Demetrius (26 October), but the feast of Blessed Josaphat was removed. These decisions were accepted with resistance, as evidenced by circulars issued by the state authorities and pastoral letters from Ryłło. ${ }^{42}$

The Bishop of Lviv, Piotr Bielanski [Ukr. Petro Bilyanskyi], also opposed the introduction of the new calendar, and thus a new myesatseslav, and accordingly sent a letter to the court in Vienna (received by the Governor's Office in Lviv on 7 September 1791). In justifying his position, he mentioned the recent uprisings in Ukraine and among Greek Catholics in Hungary. He called for a synod to be convened on this matter. ${ }^{43}$

\footnotetext{
42 Антін Степанович ПетРшевич, “Краткое известие,” 53-54; Władysław CноткоwSKI, Kościót w Galicyi 1772-1780. Historyja polityczna Kościoła w Galicyi za rzqdów Maryi Teresy, vol. 2 (Kraków: G. Gebethner i Spółka, 1909), 411; Stanisław NABYwANIEC, "Diecezja przemyska greckokatolicka 1772-1795," Premislia Christiana 5 (1992/93): 216-217.

${ }^{43}$ Антін Степанович ПЕтРшЕВич. “Краткое известие,” 53-55.
} 
The Prussian authorities were very cautious about changing the calendar lest they might induce the Uniates to convert to Eastern Orthodoxy. The government's attempts to introduce the Gregorian calendar were unsuccessful. In 1797, the number of holidays was reduced, taking into account the suggestions of Teodozy Wisłocki, the bishop of the diocese of Supraśl, established under the Prussian rule, to maintain the holidays closely connected with the Greek rite, due to the general dedication to tradition. Apart from Sundays, there are 20 public holidays left after the reduction. On the days of the abolished holidays, the authorities permitted the celebration of services, but did not force peasants to do serfdom. ${ }^{44}$

Any discussion of amendments to the calendar must take into account the concepts presented by the Bishop of Polotsk Herakliusz Lisowski. The activity of this hierarch in the diocese now situated within the borders of Russia as a result of the partitions, gives rise to a great deal of controversy. It is difficult to assess it unequivocally, both in terms of his pastoral ministry and his influence on the political situation and conditions of the functioning of the Uniate Church in the areas of the Russian partition. Bishop Lisowski devised a plan to reform the liturgy, proposing to remove the Latin customs adopted earlier by the Uniate Church. ${ }^{45} \mathrm{He}$ also presented proposed changes in the calendar, which reflected the reforms in the liturgy and rituals. In 1785, he applied to the Holy See to abolish some of the holidays sanctioned by the Synod in Zamośc. When giving arguments, he drew on the views of the governor (probably Governor of Polotsk Krechetnikov), who represented the Russian administration in the territories captured by Russia after the First Partition, claiming that "holidays destroy diligence but foster laziness

\footnotetext{
${ }^{44}$ Alfred IGNATOwICZ, "Greckokatolicka diecezja supraska (1796-1807)," Wiadomości o Kościele Archidiecezji w Białymstoku 2, no. 4 (1976): 112; Historia Kościoła w Polsce, edited by Bolesław Kumor, vol. 2/1 (Poznań-Warszawa: Pallottinum, 1979), 173-175.

${ }^{45} \mathrm{He}$ called for the abolition of read masses with the Little and Great Entrances restored, the abolition of the use of organs and the rosary prayer, as well as discontinuation of the celebration of Corpus Christi and Immaculate Conception. The Congregation for the Promotion of the Faith considered the reform proposals to be too radical and risky in the circumstances of the Uniate Church in Russia. A negative assessment was also presented by the Uniate bishops and the General Chapter of Basilians, see B. Modzelewska, "Lisowski Herakliusz," in Encyklopedia katolicka, vol. 10 (Lublin: Towarzystwo Naukowe KUL, 2004); Leonid ŻYTKOwICZ, "Lisowski Józef," in PSB, vol. 17 (Kraków: Polska Akademia Nauk, 1972); Meletiy SoloviY, De reformatione liturgica Heraclii Lisowskyj (Roma: Sumptibus PP. Basilianorum, 1950); James T. FLYNN, "Irakliii Lisowski. Metropolitan of Uniate Church (1806-1809) and Reform In the Russian Empire," The Slavonic and East European Review 77 (1999): 93-116.
} 
and drunkenness." ${ }^{46}$ In his reply of May 1785, Cardinal Leonardo Antonelli, the prefect of the Congregation for the Propagation of the Faith, pointed out that Lisowski had not presented a list of "redundant holidays," which made it impossible for the Holy See to take a decision to abolish them. ${ }^{47}$ Sill in the same year, Lisowski elaborated on the list. He proposed that the feasts of Circumcision of Christ, Epiphany, Transfiguration of the Lord and Corpus Christi be moved to Sundays, and in the case of six feast days, i.e. Annunciation to the BVM, Dormition of the BVM, Nativity of the BVM, Care of the BVM, Saints Peter and Paul, and Saint Nicholas (6 December), he requested that a permission to work be granted and the abolition of the obligation to participate in God's service. ${ }^{48}$ In his correspondence of 29 July 1786, Cardinal Antonelli argued that Lisowski should subordinate the implementation of his concepts to the measures taken by the Uniate episcopate and the king, informing him that the issue of abolishing selected feast days was already being dealt with in the Holy See by the king and metropolitan. The decisions taken to reduce public holidays would be in force in all dioceses of the Polish Republic, therefore Lisowski would also be able to implement changes in the archdiocese in his charge. Simultaneously, Cardinal Antonelli suggested that Lisowski take care of pastoral matters. ${ }^{49}$

Despite the firm stance of the Congregation for the Proliferation of the Faith, Lisowski did not give up enforcing his ideas. On 29 September 1787, Cardinal Antonelli admonished him not to reduce the number of public holidays and to celebrate both the feast of Saints Peter and Paul, as well as Blessed Josaphat. ${ }^{50}$ Also a year later (23 August 1788), Cardinal Antonelli categorically reminded Lisowski about keeping order in the calendar of holidays, observing Corpus Christi always on Thursday and celebrating the memorial of Blessed Josaphat on 16 September. In a comprehensive justification, Antonelli reminded him that it was the only day celebrated "throughout Catholic Russia." Moving the holiday of "the holy martyr for the Catholic faith and union" to following Sunday, as proposed by Lisowski, might contribute to it quickly falling into oblivion among the faithful who were busy with their work. The cardinal emphasized the special importance of this holiday for the Archdiocese of Polotsk: "[...] justice demands that the day of

\footnotetext{
${ }^{46}$ SAL, GCCCh, ref. no. 1121, p. 90.

${ }^{47}$ Ibid., 91.

${ }^{48}$ Ibid., 92.

${ }^{49}$ Ibid., 93-94.

${ }^{50}$ Ibid., 97-98.
} 
this martyr should be a feast for the whole Uniate Church, especially of the Diocese of Polotsk, which he once shepherded and in which he shed blood." 51 The position of the Holy See clearly confirms the particular importance of the veneration of that martyr for the union. Recognition of that cult was but one determinant of adopting the union.

The development of the veneration of Blessed Josaphat was an element of religious life, but it also contributed to the identity of the Uniate Church becoming distinct. Tsar Peter I's invasion of Polotsk in 1705 in order to rob the relics of the martyr from the cathedral and the murder of monks from the Basilian congregation politicized the case of Josaphat Kuntsevych. Those events made it an anti-Russian issue. Consequently, the martyr for the union became a symbol consolidating the Uniate Church in its opposition to the Orthodox Church. At the same time, the Congregation recommended that Lisowski celebrate according to the calendar established in the Synod of Zamość, and not to give preference to the date of celebration established for the non-Uniates, choosing the feast of John the Evangelist as an illustration of the problem, celebrated on 8 May by the Uniates and on 26 September by the anti-Uniates. Introduction of novel elements with regard to fasting was forbidden, and observance of the provisions of the Synod of Zamość was ordered. ${ }^{52}$ The obstruction of contacts with the Holy See and the metropolitan, caused by the Russian policy, did not permit adequate control. Lisowski's activity with respect to the implementation of his concept was hampered by his conflict with the Basilians. It is difficult to decide what was dominant in Lisowski's opinion: the illusion of faith in the possibility of reconciliation between the Russian Orthodox Church and the Holy See through maximum rapprochement of the union with the Orthodox Church, or loyalty to Russia associated with career opportunities. ${ }^{53}$ Lisowski's ideas did not reflect the opinion of the entire episcopate. They would remain part of his individual vision, which is difficult to clearly assess, especially when it comes to the degree of influence and inspiration of Russia. Even if he himself had no bad intentions, his actions were seen by Yosyf Semashko [Pol. Józef Siemaszko] and the Russian propaganda of the $19^{\text {th }}$ century in favourable context.

\footnotetext{
${ }^{51}$ Ibid., 102-103.

${ }^{52}$ Ibid.

${ }^{53}$ Володимир ОСАдчий, “Ілюзії чи відчай? Лист архиєпископа полоцького Іраклія Лісовського на тлі історії унії в Російській імперії на прикінці XVIII ст.,” Rocznik Instytutu Europy Środkowo-Wschodniej 5 (2007): 222.
} 
Multifaceted polemics and difficult manoeuvring surrounding the calendar reform undertaken by the Uniate hierarchy demonstrate the complexity of this issue and fit in with the cultural changes of the time. We see a conflict between the Enlightenment desire for organisation and standardisation on the one hand, and the sense of one's own identity on the other, the calendar being an important determinant of the latter. With respect to time measurement, Enlightenment ideas contributed to the inclusion of economic arguments in the discourse. The calendar was an indicator of religious affiliation, but above all it was an element setting one apart both within the elite circles and among neighbours and subjects. It was in these most numerous strata of society that the calendar proved to be an important factor confirming individuality as well as shaping social and cultural identity.

Despite two centuries of functioning of the union and the legitimisation of phenomena which contributed to the Uniates' identity, the awareness of their attachment to the tradition of the East remained very strong, although territorial differentiation was noticeable. The preservation of tradition had a greater significance in the dioceses of the Crown and less so in Lithuania. For the Uniate community, the measurement of time had a multi-dimensional nature. The maintenance of a distinct liturgical calendar had no impact on everyday life; for example, bishops themselves adjusted the count of time to the Gregorian calendar with respect to economic and financial documents. In an agreement concluded on 24 February 1753 between Metropolitan Jason Smogorzewski and his then coadjutor Felicjan Wołodkowicz, when establishing a financial settlement schedule, it was assumed that settlements would be made on dates specified by the "new calendar." 54 The attitudes of Uniate hierarchs towards changes in the calendar show that the measure of time had taken on a lot of cultural and political colouring. The Uniate bishops were determined to unify the calendars of the Uniate Church and the Orthodox Church.

The actions taken by the hierarchs of the Uniate Church in the $18^{\text {th }}$ century with regard to the calendar illustrate the attempt to combine and reconcile economic reasons, religious and social influences dictated by the ideas of the Enlightenment. It is not apparent that among the $18^{\text {th }}$ century elite of the Uniate Church there was a common belief that the standardisation will serve as a tool for elevating the prestige of the Uniates. This is confirmed by

\footnotetext{
${ }^{54}$ Epistolae metropolitarum kioviensium catholicorum Leonis Kiška Athanasii Szeptyckyj Floriani Hrebnyckyj (1714-1762), edited by Athanasius Welykyi (Romae: PP. Basiliani, 1959), 348-349.
} 
the choice of 25 August 1784, i.e. the feast of the Assumption (Dormition) of the Blessed Virgin Mary in the Julian liturgical calendar, for the consecration of a new church and residence of Uniate metropolitan bishops, erected according to the design of Dominik Merlini, the court architect of King Stanislaw Poniatowski, in the prestigious district of Warsaw. ${ }^{55}$

\section{BIBLIOGRAPHY}

BIEŃKOwSKI, Ludomir. "Organizacja Kościoła wschodniego w Polsce [Organisation of the Eastern Church in Poland]." Kościót w Polsce, vol. 2 [The Church in Poland], edited by Jerzy Kłoczowski, 781-1049. Kraków: Znak, 1968.

Сноткоwsкi, Władysław. Kościót w Galicyi 1772-1780. Historyja polityczna Kościoła w Galicyi za rzadów Maryi Teresy [The Church in Galicia in 1772-1780. The political history of the Church in Galicia under Maria Theresa]. Vol. 2. Kraków: G. Gebethner i Spółka, 1909.

CUBRZYŃSKA-LEONARCZYK, Maria. "Warszawskie powiązania supraskiej drukarni oo. Bazylianów [Warsaw connections of the Basilians' print house in Supraśl]." Śladami unii brzeskiej [Tracing the Union of Brest], edited by Radosław Dobrowolski and Mariusz Zemło, 275-98. Lublin-Supraśl: Acta Collegia Suprasliensis, 2010.

FLynN, James T. "Iraklii Lisowski, Metropolitan of the Uniate Chuch (1806-09) and Reform in the Russian Empire.” The Slavonic and East European Review 77 (1999): 93-116.

FrICK, David A. "Dzwony Wilna: mierzenie czasu w mieście wielu kalendarzy [The bells of Wilno: measuring time in a city of many calendars]." Czas i kalendarz [Time and calendar], edited by Zdzisław Kijas, 237-270. Kraków: Papieska Akademia Teologiczna, 2001.

KaLinKa, Walerian. Sejm Czteroletni [The Four-Year Sejm]. Vol. 2. Warszawa: Wydawnictwo Wolumen, 1991.

KnYchalsKa, Agnieszka. "Kwestia unicka w czasie Sejmu Czteroletniego [The Uniate question during the Four-Year Sejm]." Studia z dziejów XVII i XVIII wieku [Studies in the $17^{\text {th }}$ and $18^{\text {th }}$ century history], edited by Krystyn Matwijowski and Bogdan Rok, 163-169. Wrocław: Instytut Historyczny Uniwersyteatu Wrocławskiego, 2003.

KRACIK, Jan. “'Nieposłuszne Kościołowi Dziatki.’ Reakcja społeczna na papieską redukcję świąt w Polsce w 1775 r. ["Children disobedient to the Church." Social response to the papal reduction of feasts in Poland in 1775]." Analecta Cracoviensia 26 (1995): 501-509.

LIEDKE, Marzena. "Recepcja kalendarza gregoriańskiego przez litewską jednotę ewangelicko-reformowaną w świetle akt synodalnych i korespondencji. Jeszcze jeden przyczynek do dziejów wprowadzania reformy gregoriańskiej w Rzeczypospolitej [Reception of the Gregorian calendar by the Lithuanian Evangelical Reformed Union in light of synodal acts and correspondence. Yet another contribution to the history of the Gregorian reform in the Polish Republic]." Człowiek

${ }^{55}$ SAL, GCCCh, file ref. no. 294, pp. 20-21; file ref. no. 590, pp. 391-392; О. КлАдочний, “Василіясь ий монастир у Варшаві і його судба," Analecta OSBM 3 (1938/30): 585-586; Maria CUBRZYŃSKA-LEONARCZYK, "Warszawskie powiązania supraskiej drukarni oo. Basilans," Śladami unii brzeskiej, edited by Radosław Dobrowolski and Mariusz Zemło, 276-279. Lublin-Supraśl: Acta Collegia Suprasliensis, 2010. 
wobec miar i czasu w przeszłości [People in the face of measurements and time in the past], edited by Marzena Liedke and Piotr Guzowski, 76-88. Kraków: Wydawnictwo Avalon, 2007.

NABYwANIEC, Stanisław. "Diecezja przemyska greckokatolicka 1772-1795 [The Eastern Catholic diocese of Przemyśl 1772-1795].” Premislia Christiana 5 (1992/93): 9-294.

NABYWANIEC, Stanisław. Unicka archidiecezja kijowska $w$ okresie rządów arcybiskupa metropolity Felicjana Filipa Wołodkowicza 1762-1778 [The Uniate Archdiocese of Kiev under Metropolitan Archbishop Felicjan Filip Wołodkowicz 1762-1778]. Rzeszów: Poligrafia Wyższego Seminarium Duchownego w Rzeszowie, 1998.

Nowakowski, Przemysław. Problematyka liturgiczna w międzywyznaniowej polemice po Unii Brzeskiej (1596-1720) [Liturgical issues in the inter-faith polemics following the Union of Brest (1596-1720)]. Kraków: Wydawnictwo Naukowe PAT, 2004.

ОсАдчий Володимир. “Ілюзії чи відчай? Лист архиєпископа полоцького Іраклія Лісовського на тлі історії унії в Російській імперії на прикінці XVIII ст.” Rocznik Instytutu Europy Środkowo-Wschodniej 5 (2007): 217-225.

Sakowicz, Eugenuusz. Kościót prawostawny w Polsce w epoce Sejmu Wielkiego [East Orthodox Church in Poland during the Fourth-Year Sejm]. Warszawa: Warszawska Metropolia Prawosławna, 1935.

\author{
THE ATTITUDE OF UNIATE BISHOPS \\ TOWARDS CALENDAR REFORMS \\ IN THE LATTER HALF OF THE $18^{\mathrm{TH}}$ CENTURY
}

Summary

The provisions of the Union of Brest guaranteed the use of the Julian calendar in the Uniate Church. In the second half of the $18^{\text {th }}$ century, as a result of the socio-political changes and the so-called reduction in holidays in the Latin Church the question of a reformed calendar was brought up among the hierarchs of the Uniate Church. Its elaboration and corresponding debates showed that the calendar was clearly considered to be an element of identification for all the faithful and an important factor creating a sense of separateness and identity in the multidenominational and multinational Polish Republic. The issue of reforming the calendar used by the Uniate Church was raised at the Great Sejm, but a new list of feasts was compiled by Uniate bishops during the congress of $17^{\text {th }}$ September 1790 held in Warsaw. The hierarchy of the Uniate Church was also obliged to take a stance on the changes in the calendar introduced by the invading countries. The actions taken by Uniate hierarchs in the $18^{\text {th }}$ century reflect an attempt to combine economic reasons with religious ones as well as social influences dictated by the ideas of the Enlightenment.

Key words: Uniate Church; calendar reforms; Uniate bishops; $18^{\text {th }}$ century; reduction of holidays; liturgical calendar of Uniate Church.

\title{
Translated by Tomasz Patkowski
}

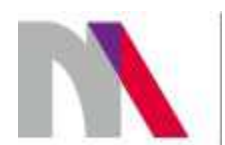

The preparation of the English version of Roczniki Humanistyczne (Annals of Arts) and its publication in electronic databases was financed under contract no. 836/P-DUN/2018 from the resources of the Minister of Science and Higher Education for the popularization of science. 